\title{
UJI EFEKTIVITAS EKSTRAK BUAH PINANG YAKI (Areca vestiaria) TERHADAP PENURUNAN KADAR GULA DARAH TIKUS PUTIH JANTAN GALUR WISTAR (Rattus norvegicus) YANG DI INDUKSI ALOKSAN
}

\author{
Raynaldo M. Ludong ${ }^{1)}$, Edwin de Queljoe ${ }^{2)}$, Herny E. I. Simbala ${ }^{1)}$ \\ ${ }^{1)}$ Program Studi Farmasi FMIPA UNSRAT Manado, 95115 \\ 2) Jurusan Biologi FMIPA UNSRAT Manado, 95115
}

\begin{abstract}
The result of phytochemical analysis showed that Pinang Yaki extracts contains tannins, flavonoids and triterpenoid. One of the compounds thought to have antidiabetic activity is flavonoids. Flavonoids are generally thought to regenerate pancreatic beta cell damage due to aloxan induction and can reduce blood glucose levels by stimulating pancreatic beta cell to produce insulin. This study aims to determine the effectiveness of areca nut extract to reduce blood sugar levels of male white wistar rats which are induced by aloxan. This Type of research is laboratory experiments using Complete Random Design (CRD). Twelve rats were divided into 4 treatment groups with each group consisting of 3 rats. The first group was the negative control group $(K-)$ only given aquades, the second Group was positive control $(K+)$ given metformin, group three was the sample treatment group (PS1) with an extract dose of $400 \mathrm{mg}$, and the sample treatment group (PS2) with an extract dose of $800 \mathrm{mg}$. Previously rats were examined the fasting blood sugar, then induced aloxan monohydrate dose of $150 \mathrm{mg} / \mathrm{kgBW}$ intraperitoneally, and blood sugar levels were examined once in every two days for 7 days. On the $8^{\text {th }}$ day extract was given and blood sugar levels were examined every two days until the $14^{\text {th }}$ day. The result showed that extract of Pinang Yaki fruit at a dosage of $400 \mathrm{mg}$ and $800 \mathrm{mg}$ had activities to reduce blood sugar levels on the $8^{\text {th }}$ to $14^{\text {th }}$ day with a decrease of $38 \mathrm{mg} / \mathrm{dL}$ for the PS1 treatment groups and $29 \mathrm{mg} / \mathrm{dL}$ for the PS2 sample treatment group.
\end{abstract}

Keywords : Areca vestiaria, Rattus Norvegicus, Blood Sugar Levels, Flavonoids

\begin{abstract}
ABSTRAK
Hasil analisis Fitokimia menunjukkan bahwa ekstrak buah Pinang yaki (Areca vestiaria) mengandung senyawa tanin, flavonoid dan triterpenoid. Salah satu senyawa yang diduga memiliki aktivitas sebagai antidiabetes adalah flavonoid. Flavonoid secara umum diduga dapat meregenerasi kerusakan sel beta pankreas akibat induksi aloksan dan dapat menurunkan kadar glukosa darah dengan merangsang sel beta pankreas untuk memproduksi insulin. Penelitian ini bertujuan mengetahui efektivitas ekstrak buah Pinang Yaki terhadap Penurunan kadar gula darah tikus putih jantan galur wistar yang dinduksi aloksan. Jenis penelitian ini ialah eksperimen laboratorium. Menggunakan Rancangan Acak Lengkap (RAL). Dua belas ekor tikus di bagi kedalam 4 kelompok perlakuan dengan masing-masing kelompok terdiri dari 3 ekor tikus. Kelompok Pertama merupakan kelompok Kontrol negative (K-) dengan hanya di berikan aquades, kelompok kedua merupakan kontrol positif (K+) yang diberikan metformin, Kelompok tiga merupakan kelompok Perlakuan sampel (PS1) dengan dosis ekstrak $400 \mathrm{mg}$, dan kelompok perlakuan sampel (PS2) dengan dosis ekstrak $800 \mathrm{mg}$. Sebelumnya tikus dilakukan pemeriksan gula darah puasa, selanjutnya diinduksi aloksan monohidrat dosis $150 \mathrm{mg} / \mathrm{kgBB}$ secara intraperitoneal, dan dilakukan pemeriksaan kadar gula darah dua hari sekali selama 7 hari. Pada hari ke-8 dilakukan pemberian ekstrak dan dilakukan pemeriksaan kadar gula darah setiap dua hari sekali sampai hari ke-14. Hasil penelitian menunjukkan bahwa ekstrak buah pinang yaki dosis $400 \mathrm{mg}$ dan $800 \mathrm{mg}$ memiliki aktivitas menurunkan kadar gula darah pada hari ke-8 sampai hari ke-14 dengan penurunan sebesar 38 mg/dL untuk kelompok perlakuan sampel PS1 dan 29 $\mathrm{mg} / \mathrm{dL}$ untuk kelompok perlakuan sampel PS2.
\end{abstract}

Kata kunci : Areca vestiaria, Rattus norvegicus, Kadar Gula Darah, Flavonoid 


\section{PENDAHULUAN}

Kesehatan merupakan keadaan sejahtera dari badan, jiwa, raga dan sosial yang memungkinkan setiap orang hidup produktif secara sosial dan ekonomi. Saat ini tingkat kesehatan menghadapi tantangan yang sangat berat, hal ini disebabkan oleh tingkat biaya kesehatan yang cenderung meningkat, seperti harga obat-obatan dan biaya rumah sakit yang semakin memperburuk kualitas hidup dan kesehatan masyarakat. Salah satu penyakit yang tergolong sangat sulit untuk disembuhkan dan dibutuhkan penanganan secara serius melalui pengobatan yaitu penyakit diabetes mellitus (Sahputra, 2008).

Kerusakan pada sel-sel beta penghasil insulin menyebabkan produksi atau sekresi isulin mengalami penurunan. Keadaan ini dapat menyebabkan kondisi hiperglikemia yang mengakibatkan terjadinya penyakit diabetes. Oleh karena itu, perlu dicari suatu obat alternatif yang mengandung bahan aktif yang berfungsi sebagai penurun kadar glukosa darah dan dapat mempercepat regenerasi sel beta. Akhir-akhir ini, komponen bahan aktif dari beberapa tanaman obat, dan bahan pangan telah dilaporkan mempunyai aktivitas biologis yang berguna untuk pengobatan penyakit diabetes secara empiris. Efek hipoglikemik komponen bioaktif pada tanaman tersebut berkontribusi dalam mengembalikan fungsi sel beta pankreas sehingga menyebabkan peningkatan sekresi insulin. Dilaporkan pula, kebanyakan tumbuhan yang mengandung flavonoid, glikosida, alkaloid, terpenoid, dan keratenoid mempunyai efek sebagai antidiabetes (Widyastuti and Suarsana, 2011).

Pinang yaki (Areca vestiaria) merupakan salah satu tumbuhan yang tumbuh di daerah Sulawesi Utara tepatnya di lereng gunung Soputan dan gunung Mahawu kabupaten Minahasa (Simbala, 2007). Menurut Simbala (2006), pinang yaki yang merupakan sejenis palem liar, ternyata merupakan tanaman multi fungsi. Masyarakat Sulawesi Utara biasanya menggunakan secara empiris tanaman ini untuk menyembuhkan berbagai macam penyakit seperti salah satunya ialah penyakit Diabetes Melitus (DM).

\section{METODOLOGI PENELITIAN}

Alat

Alat yang digunakan : Ayakan 100 mesh, oven, Glukometer Autochek,strip glukosa, gunting, sonde oral, disposible $1 \mathrm{ml}$ (One Med), batang pengaduk, timbangan analitik, sonifikator, gelas ukur (Pyrex), beker gelas (Pyrex), toples kaca, kertas saring, sarung tangan lateks, masker (SENSI Mask), botol sampel, gunting, blender, cawan petri (Pyrex), pipet tetes, kandang, tempat makan dan tempat minum tikus.

\section{Bahan}

Bahan yang digunakan: Tikus putih jantan galur wistar (Rattus novergicus) 12 ekor, ekstrak Buah Pinang Yaki (Areca vestiaria), aquades, etanol $96 \%$, Kloroform, Aloksan, Metformin, pangan tikus putih jantan galur wistar (Rattus novergicus) berupa pellet.

\section{Jenis dan rancangan penelitian}

Jenis penelitian ini ialah eksperimen laboratorium. Menggunakan Rancangan Acak Lengkap (RAL). Hewan uji dikelompokan dalam 4 kelompok masing-masing terdiri dari 3 ekor hewan uji yaitu tikus putih jantan galur wistar dengan berat rata-rata 200 gram. Kelompok 1 tidak diberi perlakuan dan sebagai kontrol negatif. Kelompok 2 dan 3 diberi perlakuan dengan dosis yang berbeda-beda yaitu $400 \mathrm{mg}$ dan $800 \mathrm{mg}$. Sementara itu 
kelompok 4 diberi perlakuan dengan dosis metformin $500 \mathrm{mg}$. Pemberian dosis terlebih dahulu dikonversikan dengan menggunakan faktor konversi untuk Manusia $70 \mathrm{~kg}$ BB ke Tikus $200 \mathrm{~g}$ BB dengan dikalikan 0,018. Sehingga pembagian perlakuan sebagai berikut:

a. Kelompok I : Tikus putih tidak diberikan perlakuan (Kontrol).

b. Kelompok II : Tikus putih dengan DM diberi dosis I (400 mg dikonversikan dalam dosis tikus menjadi $7,2 \mathrm{mg} / \mathrm{mL}$ ) ekstrak buah pinang yaki sebanyak $2 \mathrm{~mL}$ setiap 2 hari sekali, selama 7 hari.

c. Kelompok III: Tikus putih dengan DM diberi dosis II (800 mg dikonversikan dalam dosis tikus menjadi 14,4 mg/mL) ekstrak buah pinang yaki sebanyak $2 \mathrm{~mL}$ setiap dua hari sekali, selama 7 hari.

d. Kelompok IV: Tikus Putih dengan DM diberi metformin (500 mg dikonversikan ke dosis tikus menjadi $9 \mathrm{mg} / \mathrm{mL}$ ), sebanyak 2 $\mathrm{mL}$ setiap dua hari sekali, selama 7 hari.

\section{Populasi dan sampel}

Sampel yang digunakan yaitu tikus putih jantan galur wistar (Rattus norvegicus) yang berusia 2 - 3 bulan dengan bobot rata-rata 150-200 gram.

\section{Prosedur Kerja}

\section{Penyiapan hewan uji}

Hewan uji diadaptasi selama kurang lebih 1 minggu sebelum perlakuan, dilakukan adaptasi (Animal house) pada hari pertama sampai hari ketujuh. Hewan uji diadaptasikan dengan tempat tinggal barunya, dengan pemberian makanan dan minuman. Perlakuan ini disamakan pada semua tikus. Adaptasi cukup dilakukan selama 7 hari. Adaptasi ini bertujuan untuk semua objek penelitian supaya hewan uji dalam kondisi tidak stress dan dalam keadaan yang sama saat dimulai penelitian.

\section{Pengambilan sampel}

Tahap awal dilakukan dengan pengumpulan bahan baku buah Pinang Yaki yang diambil di Lereng Gunung Mahawu, Tomohon. Buah Pinang Yaki dibersihkan, dilepaskan dari tangkainya dan ditimbang berat basahnya. Buah Pinang Yaki yang telah dibersihkan dan di pisahkan dari tangkainya diangin-anginkan didalam ruangan selama kurang lebih 5 hari. Buah yang telah kering diblender sampai menjadi halus dan diayak menggunakan ayakan mesh 100 .

\section{Pembuatan ekstrak buah Pinang Yaki}

Pinang Yaki yang telah menjadi serbuk simplisia ditimbang sebanyak 500 gram dan dimasukan dalam toples kaca kemudian diekstraksi menggunakan metode maserasi dengan cara serbuk simplisia direndam dalam pelarut etanol 96\% sebanyak $2500 \mathrm{~mL}$, dibiarkan selama 5 hari pada suhu kamar dan ditutup rapat. Kemudian disaring menggunakan kertas saring. Residu yang diperoleh dilakukan remaserasi selama 2 hari. Filtrat yang peroleh dipekatkan dengan cara dievaporasi pada suhu $40^{\circ} \mathrm{C}$ sampai diperoleh ekstrak kental. Ekstrak kental serbuk simplisia buah Pinang Yaki yang di peroleh sebanyak 50,23 gram.

\section{Pembuatan larutan uji}

Pembuatan larutan uji diawali dengan menimbang ekstrak kental Buah Pinang Yaki (Areca vestiaria) sesuai dengan masing-masing dosis $(7.2 \mathrm{mg} / \mathrm{mL} ; 14.4 \mathrm{mg} / \mathrm{mL})$, kemudian masing-masing ekstrak yang telah ditimbang dimasukan dalam labu ukur $10 \mathrm{~mL}$ dan ditambahkan larutan aquadest hingga tanda tera 
dan disonifikasi sampai homogen selama 30 menit. Setelah homogen, masing-masing dosis ekstrak di masukkan ke dalam botol sampel dan diberi label. PS1 untuk ekstrak buah pinang yaki dengan dosis $7.2 \mathrm{mg} / \mathrm{mL}$ dan PS2 untuk ekstrak buah pinang yaki dengan dosis 14.4 $\mathrm{mg} / \mathrm{mL}$.

\section{Pembuatan larutan aloksan}

Serbuk aloksan monohidrat dilarutkan dengan menggunakan aquades. Dosis induksi aloksan untuk tikus ialah $150 \mathrm{mg} / \mathrm{kgBB}$ untuk pemberian secara intraperitoneal, BB tikus = 200 g, maka jumlah aloksan yang diberikan ialah $30 \mathrm{mg}$.

\section{Pembuatan larutan metformin}

Berdasarkan tabel konversi perhitungan dosis untuk berbagai jenis hewan uji dari berbagai spesies dan manusia, maka konversi dosis manusia dengan berat badan $70 \mathrm{~kg}$ pada tikus dengan berat badan $200 \mathrm{~g}$ ialah 0,018 (Ngatidjan, 1991). Dosis metformin yang dipakai untuk orang dewasa iaalah $500 \mathrm{mg}$, jadi dosis untuk tikus $200 \mathrm{gr}=500 \mathrm{mg}$ x 0,018/tikus = $9 \mathrm{mg}$ (Ngatidjan, 1991).

\section{Pemberian perlakuan \\ Pemberian larutan aloksan}

Tikus dibuat menjadi diabetes dengan menginjeksikan larutan aloksan melalui interperitonial. Aloksan diberikan pada hari pertama setelah peeriksaan Gula Darah Awal. Dengan sekali pemberian aloksan sebanyak 2 $\mathrm{mL}$ pada hari pertama. Proses penyimpanan sampai proses penyuntikan aloksan dilakukan pada suhu dingin supaya aloksan tidak rusak (Sujono dan Munawaroh, 2009).

\section{Pemberian ekstrak buah pinang yaki}

Pemberian perlakuan untuk penelitian ini masing-masing konsentrasi menggunakan 3
Tikus untuk tiap kelompok hewan uji. Ekstrak buah pinang yaki diberikan sesuai dosis perlakuan yaitu $2 \mathrm{~mL}$ pada setiap tikus untuk masing-masing konsentrasi secara oral menggunakan alat penyekok oral (Sonde) dengan dispo dua hari sekali selama 7 hari dari hari ke delapan sampai hari ke empat belas.

\section{Pemberian larutan metformin}

Pemberian perlakuan untuk kelompok pembanding dengan 3 ekor tikus sebagai hewan uji. Larutan Metformin diberikan sesuai dosis yaitu $2 \mathrm{~mL}$, perlakuan secara oral menggunakan alat penyekok oral (Sonde) dengan dispo dua hari sekali untuk satu ekor tikus selama 7 hari, dari hari ke delapan sampai hari ke empat belas.

\section{Pemeriksaan gula darah}

Sebelum dilakukan pengambilan darah, bagian ekor tikus dibersihkan terlebih dahulu dengan menggunakan alkohol $70 \%$. Selanjutnya darah diambil pada bagian ekor menggunakan autoklik sehingga keluar darah dan diukur kadar gula darah dengan alat glukometer autocheck. Caranya dengan meneteskan darah tikus yang berasal dari ekor tikus yang diteteskan pada strip glukosa yang telah dimasukkan kedalam glukometer, setelah darah diteteskan pada strip, kemudian ditunggu selama 10 detik untuk hasil dari pembacaan kosentrasi glukosa darah pada glukometer. Hasil yang tertera pada glukometer merupakan hasil dari nilai kosentrasi glukosa darah dalam satuan $\mathrm{mg} / \mathrm{dL}$.

\section{Analisis data}

Hasil percobaan yang dianalisis untuk melihat adanya perubahan yang nyata tehadap kadar gula darah dari masing-masing kelompok tikus perlakuan. Analisis data yang diperoleh diolah dengan menggunakan program SPSS 
yang meliputi, uji statistik menggunakan Kruskal Wallis Test.

\section{HASIL DAN PEMBAHASAN}

Penelitian ini dilakukan dengan menggunakan metode ekstraksi. Prinsip dari ekstraksi sendiri ialah penarikan senyawasenyawa dalam tanaman oleh pelarut yang sesuai, baik dari segi keamanan maupun kepolarannya. Ekstraksi dilakukan dengan cara maserasi simplisia buah pinang yaki (Areca vestiaria) dengan menggunakan pelarut etanol $96 \%$.

Ekstrak etanol adalah sediaan yang paling umum digunakan pada penelitian awal mengenai aktivitas farmakologis suatu tanaman. Hal ini dikarenakan pada penelitian awal seperti ini, masih belum diketahui senyawa mana yang bertanggung jawab atas efek farmakologis dari tanaman, oleh karena itu perlu digunakan pelarut universal yang dapat melarutkan metabolit sekunder dari berbagai tingkat polaritas, seperti etanol yang bersifat semi polar (Yasmiwar et al., 2016).

Hewan uji yang digunakan dalam penelitian ini ialah tikus putih jantan galur wistar yang memenuhi syarat untuk digunakan dalam penelitian. Adapun hasil penelitian yang di dapatkan dari penelitian ini pada hari pertama saat pemeriksaan gula darah puasa (T0), pada saat pemberian aloksan dari hari pertama sampai hari ke tujuh dan pemberian ekstrak buah pinang yaki dan juga metformin dari hari ke delapan sampai hari ke empat belas, dapat di lihat pada tabel berikut.

Tabel 1. Rata-rata Kadar Gula Darah Tikus Selama Perlakuan (mg/dL)

\begin{tabular}{ccccccccccc}
\hline & \multicolumn{1}{c}{ Waktu } \\
\cline { 2 - 10 } Perlakuan & T0 & T1 & T3 & T5 & T7 & T8 & T10 & T12 & T14 \\
\hline K- & 93.67 & 93.67 & 79.67 & 112.33 & 69.00 & 93.33 & 96.33 & 105.67 & 74.33 \\
\hline PS1 & 95.67 & 120.00 & 117.00 & 144,67 & 123.33 & 90.33 & 101.00 & 113.00 & 85.33 \\
PS2 & 111.33 & 123.33 & 97.67 & 124.67 & 137.33 & 95.33 & 92.33 & 116.00 & 108.33 \\
\hline K+ & 64.33 & 87.33 & 117.33 & 169.33 & 156.33 & 115.00 & 56.33 & 75.00 & 101.67
\end{tabular}

Keterangan :

T0 :Rata-rata kadar gula darah puasa tikus.

T1-T14 :Waktu Pemberian Perlakuan dari Hari Pertama sampai hari ke Empat belas.

K- $\quad$ :Kelompok Kontrol Negatif dengan Pemberian aquades dari T1-T14.

PS1 :Kelompok Perlakuan Sampel ekstrak buah pinang yaki dosis 400mg (7,2 $\mathrm{mg} / \mathrm{mL}$ ), dengan pemberian aloksan dari T1-T7, dan Pemberian ekstrak dari T8-T14.

PS2 :Kelompok Perlakuan Sampel ekstrak buah pinang yaki dosis $800 \mathrm{mg}(14,4$ $\mathrm{mg} / \mathrm{mL}$ ), dengan pemberian aloksan dari T1-T7, dan Pemberian ekstrak dari T8-T14.

$\mathrm{K}+\quad$ :Kelompok Kontrol Positif, dengan pemberian aloksan dari T1-T7, dan Pemberian larutan metformin 500mg dari T8-T14.

Sebelum dilakukan pengujian, semua tikus dipuasakan selama 8 jam dengan tidak diberikan makanan agar tidak mempengaruhi absorbsi obat dalam tubuh. Setelah dipuasakan, semua tikus diperiksa kadar gula darah puasa (T0) dan diperoleh data kadar gula darah puasa 
tikus berada pada keadaan normal dengan ratarata 64,33-111,33 mg/dL. Kusumawati (2004), menyatakan bahwa kadar gula darah puasa normal pada tikus dalam rentang antara 50-135 $\mathrm{mg} / \mathrm{dL}$.

Kelompok kontrol negatif yang hanya diberikan aquades tanpa diberikan perlakuan apapun, baik pemberian aloksan maupun ekstrak. Rata-rata kadar gula darah kelompok kontrol negatif dapat dilihat pada tabel di atas. Hasil pengukuran kadar gula darah dibandingkan dengan kelompok perlakuan lainnya, kadar gula darah kelompok negatif tidak mengalami kenaikan yang tinggi maupun penurunan yang signifikan dari waktu T0 sampai pada waktu T14, dengan kata lain kontrol negatif memiliki kadar gula darah yang normal. Penggunaan aquades pada kelompok kontrol negatif hanya sebagai pembanding untuk melihat peningkatan maupun penurunan kadar gula darah dengan perlakuan kelompok positif maupun kelompok sampel ekstrak buah pinang yaki.

Pembuatan diabetes pada tikus dilakukan dengan menginduksi larutan aloksan $150 \mathrm{mg} / \mathrm{kgBB}$ secara intraperitonial pada tikus wistar (Sujono dan Munawaroh, 2009). Larutan aloksan dibuat dengan cara melarutkan serbuk aloksan monohidrat menggunakan aquabidest steril of injection. Hal ini disebabkan aloksan merupakan salah satu agen diabetogenik yang bersifat toksik, terutama terhadap sel beta pankreas yang apabila diberikan kepada hewan uji seperti tikus maka akan menyebabkan hewan uji menjadi diabetes. Aloksan bereaksi dengan merusak substansi esensial di dalam sel beta pankreas sehingga menyebabkan berkurangnya granula-granula pembawa insulin di dalam sel beta pankreas (Manurung, 2012).

Kondisi hiperglikemia pada hewan uji dicapai dengan cara semua tikus diinduksi larutan aloksan dengan dosis $150 \mathrm{mg} / \mathrm{kgBB}$. Pada hari pertama (T1) setelah diinduksi dengan aloksan, dan dilakukan pemeriksaan 1.5 jam kemudian, hasil rata-rata kadar gula darah dari kelompok perlakuan tikus kelompok kontrol positif, PS1, dan PS2 semuanya mengalami kenaikan antara 87.33-123.33 mg/dL. Begitu pula kadar gula darah Tikus pada $\mathrm{T} 3$, T5, dan $\mathrm{T} 7$ rata-rata pengalami kenaikan. Kenaikan kadar gula darah paling besar terjadi pada T5 meskipun ada beberapa tikus yang mengalami penurunan, namun secara rata-rata semua kelompok pengujian mengalami peningkatan kadar gula darah. Hal ini menunjukan telah terjadi penyerapan glukosa oleh tubuh tikus dikarenakan pengaruh fisiologis tubuh tikus itu sendiri, sehingga telah tercapai kondisi peningkatan kadar gula darah pada kelompok perlakuan tikus tersebut. Kemampuan dari aloksan yaitu menimbulkan diabetes juga tergantung pada dosis senyawa, jalur penginduksian, hewan percobaan dan status gizinya (Amma, 2009), hal ini yang menyebabkan kenaikan gula darah pada tikus berfariasi dan kadang mengalami penurunan dengan sendirinya.

Kelompok kontrol positif yang diberikan suspensi Metformin $500 \mathrm{mg}$ (9 $\mathrm{mg} / \mathrm{mL}$ ) menunjukkan hasil pengukuran kadar gula darah pada T8 telah mengalami penurunan, begitu pula pada T10 dan T12 telah terjadi penurunan yang signifikan. Akan tetapi pada T14 terjadi peningkatan kadar gula darah dari kelompok kontrol positif yaitu sebesar $26.67 \mathrm{mg} / \mathrm{dL}$. Hal ini dapat di karenakan tikus pada kontrol positif mengalami stress akibat faktor lingkungan maupun kondisi kesehatan yang mengakibatkan terjadinya peningkatan kadar gula darah tikus.

Hasil pengukuran kadar gula darah pada kelompok perlakuan sampel satu (PS1) yang 
diberikan ekstrak buah pinang yaki dengan dosis $400 \mathrm{mg}(7.2 \mathrm{mg} / \mathrm{mL})$, menunjukkan penurunan kadar gula darah pada T8, yang sebelumnya kadar gula darah tikus sebesar $123.33 \mathrm{mg} / \mathrm{dL}$ pada $\mathrm{T} 7$, menjadi $90.33 \mathrm{mg} / \mathrm{dL}$ pada T8, akan tetapi mengalami kenaikan kembali kadar gula darah pada T10 dan T12, namun terjadi penurunan kadar gula darah dari T12 ke T14 sebesar $27.67 \mathrm{mg} / \mathrm{dL}$. Dengan demikian dapat dikatakan bahwa ekstrak buah pinang yaki dengan dosis $400 \mathrm{mg}(7.2 \mathrm{mg} / \mathrm{mL})$ dapat memberikan efek menurunkan kadar gula darah tikus pada T14.

Pada kelompok perlakuan sampel dua (PS2) yang diberikan ekstrak buah pinang dengan dosis $800 \mathrm{mg}(14.4 \mathrm{mg} / \mathrm{mL})$, menunjukkan hasil terjadi penurunan kadar gula darah pada waktu T8 sampai T10, dimana kadar gula darah tikus pada T7 sebesar 137.33 $\mathrm{mg} / \mathrm{dL}$ menjadi $95.33 \mathrm{mg} / \mathrm{dL}$ pada T8 dan 92.33 $\mathrm{mg} / \mathrm{dL}$ pada T10. Akan tetapi terjadi peningkatan kadar gula darah pada T12 menjadi $116.00 \mathrm{mg} / \mathrm{dL}$. Sama halnya dengan kelompok PS1, pada kelompok PS2 juga terjadi penurunan pada T14 sebesar $7.67 \mathrm{mg} / \mathrm{dL}$. Dengan demikian, ekstrak buah pinang yaki dengan dosis $800 \mathrm{mg}$ (14.4 mg/mL), dapat memberikan efek menurunkan kadar gula darah pada tikus pada T14 meskipun tidak terlalu besar.

Rata-rata peningkatan dan penurunan kadar gula darah pada kelompok perlakuan baik kontrol negatif yang hanya diberikan aquades, kontrol positif yang diberi metformin, maupun perlakuan sampel PS1 dan PS2 yang diberi ekstrak buah pinang yaki, dapat dilihat pada saat gula darah puasa T0, setelah pemberian aloksan T7 dan setelah pemberian ekstrak buah pinang yaki dan metformin T14, dapat dilihat dari tabel 2.
Tabel 2. Rata-rata Kadar Gula Darah Tikus saat Puasa, Pemberian Aquades, Setelah diberikan aloksan, dan setelah di berikan ekstrak Buah Pinang Yaki dan Metformin.

\begin{tabular}{cccc}
\hline \multirow{2}{*}{ Kelompok } & \multicolumn{3}{c}{$\begin{array}{c}\text { Rata-rata Kadar Gula } \\
\text { Darah Tikus (mg/dL) }\end{array}$} \\
\cline { 2 - 4 } & T0 & T7 & T14 \\
\hline K- & 93.67 & 69.00 & 74.33 \\
PS1 & 95.67 & 123.33 & 85.33 \\
PS2 & 111.33 & 137.33 & 108.33 \\
K+ & 64.33 & 156.33 & 101.67 \\
\hline
\end{tabular}

Berdasarkan data tersebut kelompok kontrol negatif yang hanya diberikan aquades memiliki kadar gula darah yang normal serta tidak memiliki peningkatan dan penurunan kadar gula darah yang signifikan. Kadar gula darah dari kelompok kontrol negatif antara $69.00 \mathrm{mg} / \mathrm{dL}-93.67 \mathrm{mg} / \mathrm{dL}$. Sementara itu untuk kelompok kontrol positif sendri yang diberikan aloksan dan metformin memilik peningkatan kadar gula darah yang cukup signifikan setelah pemberian aloksan dari gula darah puasa T0 $64.33 \mathrm{mg} / \mathrm{dL}$, menjadi $156.33 \mathrm{mg} / \mathrm{dL}$ pada T7, dan mengalami penurunan kadar gula darah yang signifikan setelah pemberian metformin pada T14 menjadi $101.67 \mathrm{mg} / \mathrm{dL}$.

Untuk kelompok perlakuan sampel PS1 mengalami peningkatan kadar gula darah setelah pemberian aloksan yaitu dari T0 sebesar $95.67 \mathrm{mg} / \mathrm{dL}$ menjadi $123.33 \mathrm{mg} / \mathrm{dL}$ pada T7,dan mengalami penurunan kadar gula darah setelah pemberian ekstrak buah pinang yaki dosis $400 \mathrm{mg}$ menjadi $85.33 \mathrm{mg} / \mathrm{dL}$ pada T14. Untuk kelompok perlakuan sampel PS2 mengalami peningkatan kadar gula darah setelah pemberian aloksan yaitu dari T0 sebesar $111.33 \mathrm{mg} / \mathrm{dL}$ menjadi $137.33 \mathrm{mg} / \mathrm{dL}$ pada $\mathrm{T} 7$, dan mengalami penurunan kadar gula darah setelah pemberian ekstrak buah pinang yaki dosis $800 \mathrm{mg}$ menjadi $108.33 \mathrm{mg} / \mathrm{dL}$ pada T14. Untuk lebih jelasnya mengenai peningkatan dan 
penurunan kadar gula darah tikus dapat dilihat dari grafik dibawah ini.

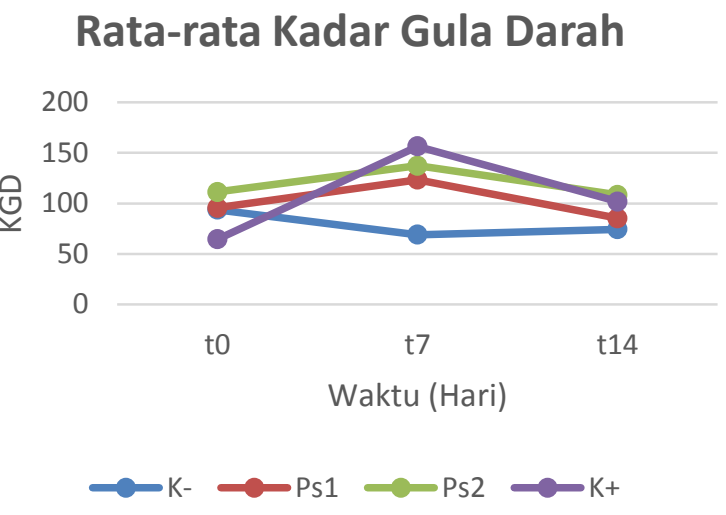

Gambar 1. Rata-rata peningkatan dan penurunan kadar gulah darah pada tikus

Pada grafik di atas terlihat peningkatan dan penurunan kadar gula darah tikus yang tajam setelah pemberian aloksan dan perlakuan sampel pada kelompok kontrol negatif, diikuti kelompok PS1, PS2 dan kelompok kontrol positif. Kelompok kontrol negatif yang hanya diberi aquadest juga mengalami penurunan dan peningkatan kadar gula darah yang lebih stabil. Sementara itu untuk kelompok perlakuan PS1, PS2 dan kontrol negatif memiliki peningkatan dan penurunan kadar gula darah yang cukup signifikan. Untuk mengetahui ada tidaknya penurunan kadar gula darah kelompok tikus yang di beri perlakuan (PS1,PS2, K+) maka dilakukan perhitungan $\Delta \mathrm{GD}$ yang dihitung dari kadar gula darah setelah induksi aloksan (T7) dikurangi dengan kadar gula darah setelah pemberian perlakuan (T14). Penurunan kadar gula darah tersebut kemudian dibuat rataratanya dan digolongkan berdasarkan kelompok perlakuan. Penurunan rata-rata yang didapat dari ketiga perlakuan adalah sebagai berikut:
Tabel 3. Rata-rata Penurunan Kadar Gula Darah Tikus setelah diberi Ekstrak Buah Pinang Yaki dan Metformin

\begin{tabular}{cc} 
Kelompok & $\begin{array}{c}\text { Rata-rata Penurunan Kadar } \\
\text { Gula Darah Tikus (mg/dL) }\end{array}$ \\
\hline PS1 & 38.00 \\
PS2 & 29.00 \\
K+ & 54.67 \\
\hline
\end{tabular}

Berdasarkan table di atas maka dapat di katakan bahwa kelompok kontrol positif yang diberikan metformin memiliki penurunan kadar gula darah paling besar di bandingkan dengan perlakuan Pemberian kedua sampel Ekstrak Buah Pinang Yaki. Pemilihan metformin sebagai pembanding dianggap tepat, selain obat ini sering digunakan juga karena mekanisme kerja metformin dalam tubuh yaitu dengan cara memperbaiki sensitivitas hepar dan jaringan perifer terhadap insulin tanpa mempengaruhi sekresi insulin. Efek ini terjadi karena adanya aktivasi kinase di sel (AMP-activated kinase). Di samping itu, metformin meningkatkan pemakaian glukosa oleh sel usus sehingga menurunkan glukosa darah dan juga diduga menghambat absorbsi glukosa di usus sesudah asupan makan (Soegondo, 2006).

Selanjutnya diikuti dengan PS1 dengan dosis $400 \mathrm{mg}(7,2 \mathrm{mg} / \mathrm{mL})$ yang mengalami penurunan kadar gula darah kedua terbesar dan terakhir PS2 dengan dosis 800mg (14.4 $\mathrm{mg} / \mathrm{mL}$ ). Hal ini menunjukan bahwa ekstrak buah pinang yaki dapat memberikan efek penurunan kadar gula darah. Penurunan kadar gula darah yang di hasilkan dari ekstrak buah pinang yaki tersebut tidak lepas dari adanya kadungan senyawa bioaktif pada buah pinang yaki yang salah satunya adalah Flavonoid yang merupakan salah satu antioksidan paling baik.

Hasil analisis Fitokimia menunjukkan bahwa ekstrak buah Pinang yaki (Areca vestiaria) mengandung senyawa tanin, flavonoid dan triterpenoid. Senyawa-senyawa 
tersebut berpotensi sebagai agen pendamping kemoterapi (Anggraeni, 2017). Penelitian yang dilakukan oleh Ismail, et al., (2012) juga menyatakan bahwa total fenolik ekstrak biji buah pinang Yaki adalah $85,9 \mathrm{mg} / \mathrm{kg}$ sedangkan antioksidan sebesar 88,2\%. Sehingga berdasarkan penelitian tersebut pinang yaki dapat digunakan sebagai antioksidan dan dapat digunakan sebagai alternative terapi penyakit degeneratif.

Flavonoid secara umum diduga dapat meregenerasi kerusakan sel beta pankreas akibat induksi aloksan dan dapat menurunkan kadar glukosa darah dengan merangsang sel beta pankreas untuk memproduksi insulin. Selain itu flavonoid juga dapat berperan sebagai antioksidan dengan mengikat radikal bebas sehingga dapat mengurangi stres oksidatif. Jika stres oksidatif berkurang maka dapat mengurangi resistensi terhadap kerja insulin dan dapat mencegah perkembangan disfungsi dan kerusakan sel beta pancreas (Muhtadi et al., 2012).

Aktivitas antioksidan mampu menangkap radikal bebas penyebab kerusakan sel beta pankreas dan menghambat kerusakan sel beta pankreas, sehingga sel beta yang tersisa masih tetap berfungsi. Antioksidan tersebut diperkirakan mampu melindungi sejumlah selsel beta yang tetap normal, sehingga memungkinkan terjadinya regenerasi sel-sel beta yang masih ada melalui proses mitosis atau melalui pembentukan pulau baru dengan cara proliferasi dan diferensiasi endokrin dari sel-sel ductal dan ductular (Suryani, et al., 2013).

Untuk memperoleh data yang lebih spesifik mengenai pengaruh ekstrak buah pinang yaki dan metformin maka dilakukan Pengujian signifikansi Ekstrak Buah Piang Yaki dan Metformin menggunakan uji statistik dengan analisis Kruskal-Wallis Test dengan aplikasi SPSS.

Nilai signifikansi atau Sig.> 0.05 (0.584 $>0.05)$, maka H0 diterima yaitu tidak terdapat perbedaan bermakna antara ekstrak buah pinang yaki dengan metformin. Hal ini menunjukan bahwa ekstrak buah pinang yaki memiliki efektifitas terhadap penurunan kadar gula darah tikus, karena dapat memberikan efek penurunan kadar gula darah yang hampir sama atau tidak jauh berbeda dengan metformin.

\section{KESIMPULAN}

Berdasarkan hasil penelitian diatas maka dapat di simpulkan bahwa, Ekstrak Buah Pinang Yaki (Areca vestiaria) dapat memberikan efek terhadap penurunan kadar gula darah tikus putih jantan galur wistar (Rattus norvegicus L) yang diinduksi aloksan.

\section{SARAN}

1. Perlu diadakan penelitian lebih lanjut untuk menentukan dosis efektif ekstrak buah pinang yaki yang berpengaruh dalam menurunkan kadar gula darah, yaitu dosis terbawah dan teratas dari ekstrak buah pinang yaki (Areca vestiaria).

2. Perlu pemberian dosis aloksan secara berulang yang menyebabkan kerusakan sel beta pankreas yang ireversibel sehingga pengaruh ekstrak buah pinang yaki (Areca vestiaria) dalam menurunkan kadar gula darah dapat terlihat lebih jelas.

\section{DAFTAR PUSTAKA}

Amma, R. 2009. Efek Hipoglikemik Ekstrak Daun Murbei (Morus Multicaulis) Terhadap Kadar Glukosa Darah Tikus Dm. [Tesis]. Program Studi Gizi Masyarakat Dan Sumberdaya Keluarga IPB.

Anggraeni, D.A.R., Widdhi, B., Herni, S., 2017. Pengaruh Ekstrak Etanol Buah 
Pinang Yaki (Areca vestiaria) Terhadap Gambaran makroskopis Organ Jantung Pada Tikus Putih Jantan Galur Wistar (Rattus norvegicus). Jurnal Ilmiah Frmasi. Vol. 6 No. 3 Agustus 2017, 2302-2493

Ismail, J., Runtuwene, M.R.J., Fatimah, F. 2012. Penentuan Total Fenolik dan Uji Aktivitas Antioksidan pada Biji dan Kulit Buah Pinang Yaki (Areca vestiaria Giseke). Jurnal Ilmiah Sains, 12(2), 8488.

Kusumawati, D., 2004. Bersahabat Dengan Hewan Coba. Gadjah Mada University Press. Yogyakarta.

Manurung, S. 2012. Efek Antihiperglikemik dari Ekstrak kulit Buah Manggis (Garcia mangostana L.) terhadap Tikus Putih Jantan Galur Wistar (Rattus norvegicus L.) yang Diinduksi Sukrosa. Pharmacon. Jurnal Ilmiah. FarmasiUNSRAT Vol.1 No.02. ISSN 2302 2493, Hal. 58-67

Muhtadi., Eni Setyowati., Tanti Azizah, 2012. Aktivitas Antidiabetes Melitus Ekstrak Kulit Buah Jeruk Manis (Citrus sinensis) dan Kulit Buah Kelengkeng (Euphoria longan (Lour.)Steud) Terhadap Tikus Putih Jantan Galur Wistar yang Diindukdi Aloksan. Jurnal Penelitian Sains \& Teknologi, Vol. 13, No. 1, April 2012: 21 - 30

Ngatidjan. 1991. Petunjuk Laboratorium Metode Laboratorium dalam Toksikologi. Yogyakarta: Pusat Antar Universitas Bioteknologi UGM, pp: 94152.

Sahputra, F.M. 2008. Potensi Ekstrak kulit Buah Salak sebagai Antidiabetes [skripsi]. FMIPA Institut Pertanian Bogor, Bogor.

Simbala, 2006. Kajian Etnobotani, Proksimat dan Fitokimia Pinang Yaki (Areca vestiaria Giseke). Eugenia 2006. 12:173-183
Simbala, H. E. I. 2007. Keanekaragaman Floristik dan pemanfaatan Sebagai Tumbuhan Obat di Kawasan Konservasi II Taman Nasional Bogani NaniWartabone (Kabupaten Bolaang Mongondow, Sulawesi Utara). [Disertasi]. Institut Pertanian Bogor, Bogor

Soegondo S. 2006. Farmakoterapi pada Pengendalian Glikemia Diabetes Melitus Tipe 2 dalam Buku Ajar Ilmu Penyakit Dalam. Jakarta: Pusat Penerbitan Fakultas Ilmu Penyakit Dalam FKUI.

Sujono T.A., Munawaroh, P. 2009. Interaksi Quercetin Dengan Tolbutamid: Kajian Terhadap Perubahan Kadar Glukos Darah Tikus Jantan Yang Diinduksi Aloksan. Jurnal Penelitian Sains \& Teknologi. Vol 10:2, 121-129

Suryani, Nani., Endang, Tinny., Aulanni'am, 2013. Pengaruh Ekstrak Biji Metanol terhadap Peningkatan Kadar Insulin, Penurunan Ekspresi TNF- $\alpha$ dan Perbaikan Jaringan Pankreas Tikus Diabetes, Jurnal Kedokteran Brawijaya, 27 (23)

Widyastuti, S., I Nyoman Suarsana. 2011. Ekstrak Air Tapak Dara Menurunkan Kadar Gula dan Meningkatkan Jumlah Sel Beta Pankreas Kelinci Hiperglikemia. Jurnal Veteriner. 12(1): 7-12.

Yasmiwar, S., Muhtadi, A., Moelyono, M., Arifin, P.C., 2016. Aktivitas Antidiabetes Ekstrak Etanol Daun Iler (Plectranthus scutellarioides (L.) R.Br.) Pada Tikus Putih Galur Wistar Dengan Metode Induksi Aloksan. Jurnal Farmaka. Vol. 14 No. 2 